\title{
The Role of Organizational Culture and Transformational Leadership on Work Motivation in a Regional Government Employees
}

\author{
Apid Junaedi $^{1 *}$, Widodo Sunaryo ${ }^{2}$, Didik Notosudjono ${ }^{3}$ \\ ${ }^{1,2,3}$ Pakuan University, Indonesia
}

\begin{abstract}
This research is motivated by the idea that the motivation of local government employees is needed to be able to produce service performance to the community in the context of bureaucratic reform to realize good governance. The purpose of this study was to find the influence of organizational culture and transformational leadership on employee motivation in a regional government, using the path analysis method. The sample in this study was 153 echelon IV employees / supervisory officials. The results found the fact that organizational culture has a significant effect on employee motivation. Meanwhile, transformational leadership does not influence employee work motivation.
\end{abstract}

Keywords: Organizational culture, transformational leadership, work motivation.

\section{INTRODUCTION}

The role of the government which functions as a public servant is very important to maintain credibility and as an obligation to the community as taxpayers and owners of sovereignty in Indonesia, so the performance of government organizations is expected to meet the needs of society and public service organizations must be innovative to meet public demand to improve good services. , effective, efficient, and accountable. Recognizing the demands of the community, one of the efforts made is to implement a national policy regarding bureaucratic reform which is programmed thoroughly for all government agencies, both central and autonomous. This aims to create a reliable, modern bureaucratic institution with a professional ASN. Innovation in governance and public services is part of the policy so that the innovativeness of employees is a demand so that they can produce good and useful innovations. Specifically for local governments, this increase in innovation aims to create competitive regions, have competitive advantages in community service, empowerment, and increase community participation besides that it is expected to increase regional independence in the management of their government (PP No. 38 of 2017). So that from the management side, there needs to be an increase, especially in the management of the State Civil Service Human Resources (ASN) in developing innovative behavior. Specifically for local governments, this increase in innovation aims to create competitive regions, have competitive advantages in community service, empowerment, and increase community participation besides that it is expected to increase regional independence in the management of their government (PP No. 38 of 2017). So that from the management side, there needs to be an increase, especially in the management of the State Civil Service Human Resources (ASN) in developing innovative behavior. Specifically for local governments, this increase in innovation aims to create competitive regions, have competitive advantages in community service, empowerment, and increase community participation besides that it is expected to increase regional independence in the management of their government (PP No. 38 of 2017). So that from the management side, there needs to be an increase, especially in the management of the State Civil Service Human Resources (ASN) in developing innovative behavior.

The Regional Government of Bogor Regency as one of the buffer areas for the capital city of Jakarta certainly has a very strategic role, so it must be a good area in managing government and providing public services. The advantage of this geographical position must be the basic capital in the effort to realize a competitive and independent region as an autonomous region, as is the vision of Bogor Regency 2018-2023, namely "The realization of an advanced, comfortable and civilized Bogor Regency". Thus an apparatus that has advanced thinking is needed in producing creative ideas and can implement them into a form of innovation in carrying out work tasks. 
As the implementation of the bureaucratic reform policy that has been mandated by the central government, several steps have been taken by the Bogor Regency Government, including; 1) establish the organizational culture "GERCEP" as an acronym for Agile, Effective, Responsive, Thorough, Efficient and Professional, which is expected to be a valuable guide for employees in working to organize government and provide services to the community, 2) develop Transformational Leadership practices to be able to encourage for employees to work well and professionally, and 3) running programs that can increase work motivation both intrinsic and extrinsic elements. The results of the preliminary survey on employee innovativeness in the Bogor Regency Government show the following; official notes/policy materials/staff review in their duties/jobs. b)There are 50\% of employees who have problems in public services/services, which can be seen from the number of employees who have internal problemsproduce innovative public service/service products according to the demands of society, so that satisfaction with the services of government agencies is still far from expectations. c)There are $39 \%$ of employees who have problems in the system, which can be seen from the number of problem employeesin system innovation in supporting their duties/jobs, where employees only carry out tasks with a preexisting system without much change. d)There are 30\% of employees who have problems in organizational development, which can be seen from the number of employees who have internal problemsincreasing the role and function of the organization/structure innovation according to the task/job demands. e)There are $40 \%$ of employees who have problems in process innovation, where this can be seen from the number of employees who have problems in making innovative procedures in completing tasks/jobs, where there are not many standard operating procedures (SOPs) that facilitate the completion of tasks/jobs. f)There are 32\% of employees who have problems in management process innovation, where it can be seen that many employees have problems in improving management function (planning, organizing, implementing, and supervising) according to the latest developments, and g)There are $48 \%$ of employees who have problems in method innovation, this can be seen from the number of employees who have problems implementing new procedures for completing work.

Based on this background, the problem to be answered in this study is to find out the effect of Organizational Culture and Transformational Leadership on Work Motivation on Employees in the Bogor Regency Government.

\section{LITERATURE REVIEW AND HYPOTHESIS DEVELOPMENT}

\section{A. Organizational Culture and Employee Work Motivation}

Organizational culturesubmitted by Robbins \& Coulter (2017) organizational culture is described as shared values, principles, traditions, and ways of doing things that influence the way members of the organization act and that differentiate the organization from other organizations. Organizational culture factors that are considered very appropriate are 1)Innovation and risk-taking: the extent to which employees are encouraged to be innovative and take risks. 2) Attention to details: the extent to which employees are expected to demonstrate accuracy, analysis, and depth of attention to details. 3) Outcome orientation: the extent to which management focuses on results or outcomes rather than on the techniques and processes to achieve these results. 4) People orientation: the extent to which management decisions take into account the impact of work results on people in the organization. 5) Team orientation: the extent to which work activities are coordinated in teams rather than individuals. 6) Aggressiveness: the extent to which people are aggressive and competitive rather than relaxed. 7) Stability: the extent to which organizational activities emphasize the importance of maintaining the status quo rather than growth.

Work Motivation according to George et al. (2005) are psychological forces that determine the direction of a person's behavior in an organization, the level of one's efforts, and the level of one's persistence. Work behavior that is motivated from within is behavior that is done for its own sake is called intrinsic motivation. Work behavior that is motivated from outside is behavior that is done to obtain material or social rewards or to avoid punishment is called extrinsic motivation. According to Gibson et al., (1991) is a concept that describes the forces that work on or within an individual to initiate and direct behavior, its dimensions include 1) A set of extrinsic conditions, the work context. That includes salary, status, and working conditions. 2) as per intrinsic conditions, job content, these include feelings of accomplishment, increased responsibility, and recognition. Devadass (2011)concludes that work motivation is a phenomenon associated with people in the context of work, who are described as a series of internal and external forces that initiate work-related behavior, and determine their shape, direction, intensity, and duration. The external dimension includes environmental forces (systems, 
organizational rewards, the nature of the work being done). The internal dimension is the power attached to the person (individual needs and motives). and determine their shape, direction, intensity, and duration. The external dimension includes environmental forces (systems, organizational rewards, the nature of the work being done). The internal dimension is the power attached to the person (individual needs and motives). and determine their shape, direction, intensity, and duration. The external dimension includes environmental forces (systems, organizational rewards, the nature of the work being done). The internal dimension is the power attached to the person (individual needs and motives).

Research result from Yusof et al. (2016) concluded that organizational culture $(r=0.546, p<0.05)$ has a positive influence on employee motivation. As for researchLin \& Liu (2012)concluded that work motivation was positively related to the perception of innovation ( $\mathrm{y} 04=0.023 ; \mathrm{p}<001)$. Chen et al. (2010)concluded that work motivation is intrinsic $(\mathrm{F}=33.96, \mathrm{p}<0.001)$ and Extrinsic $(F=4.54, \mathrm{p}<0.001)$ has a significant effect on the innovative behavior of workers. Fischer et al. (2019) concluded that Extrinsic and Intrinsic Motivation together have a significant positive interaction effect on innovation $(b=0.23, p=0.024)$. So it can be concluded that Organizational Culture has an influence on Work Motivation. Based on the previous research analysis above, the first hypothesis of this study is:

\section{H1: Organizational culture has a significant effect on employee motivation}

\section{B. Transformational Leadership and Employee Work Motivation}

According to Colquitt et al. (2009), transformational leadership is leadership that involves inspiring all its members to commit to a common vision that gives meaning to developing their own potential and problems from a new perspective. The dimensions of transformational leadership are; a) Idealized influence, ideal influence. b) Inspirational motivation or foster enthusiasm. c) Intellectual stimulation, stimulating intellectually. d) Individualized consideration or individual attention. The opinion of Bass and Riggio (2006: 3-7) are those who stimulate and inspire followers and both achieve extraordinary results, in the process, develop their leadership capacity, which consists of Idealized Influence (II), influential ideal,Individualized Consideration (IC) or Individual consideration.

Northouse (2018) states that transformational leadership is defined as a process by which a person engages with others and creates relationships that increase the level of motivation and morality in both the leader and the followers, dimensions that include; 1) Idealized Influence. Or charisma, idealized influence describes a leader who acts as a strong role model for followers. 2) Inspirational motivation, inspire them through motivation to commit and part of a shared vision in the organization. 3) Intellectual stimulation, leadership that stimulates followers to be creative and innovative. 4) Individualized consideration, the leader providing a favorable climate in which they listen carefully to the individual needs of the followers. Research research results from Aunjum et al. (2017)show four dimensions of leadership respectively, namely Idealized Influence $(r=0.501, p<0.001)$, Inspirational Motivation $(r=0.734, p<0.001)$, Intellectual Stimulation $(r=0.633, p<0.001)$, Individualized Consideration $(r=0.633, p<0.001)$ ) has a significant effect on employee motivation. Based on the analysis of the previous research above, the second hypothesis of this study is:

\section{H2: Transformational leadership has a significant effect on employee motivation}

\section{RESEARCH METHODS}

Based on the hypotheses that have been compiled, to prove this, field research was carried out on Bogor Regency employees in the scope of services/agencies, which was carried out from March 2020 to July 2020, with the following coverage:

\section{A. Population and Sample Research}

The study population was 247 employees with echelon IV positions/supervisors who were actively working in offices/agencies in the Bogor Regency Government. The sample determination used the Slovin formula with an error rate of $5 \%$ so that the sample size of this study was 153 people. 


\section{B. Research Framework}

Research is to determine the effect of organizational culture and transformational leadership variables on work motivation so that the constellation of this research model is as follows:

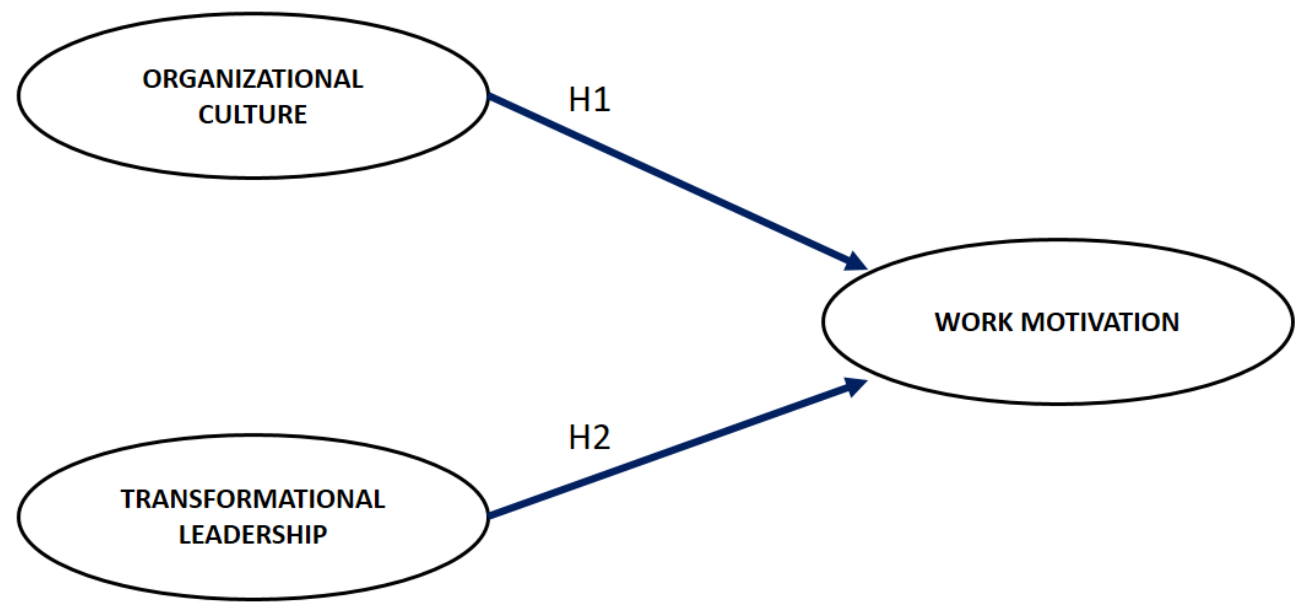

Figure 1. Research Model

\section{Data Collection Techniques}

The collection of related data related to organizational culture, transformational leadership, and work motivation is by distributing questionnaires filled out by the employees concerned (echelon IV/supervisors), the assessment also uses a Likert scale (1-5). All statements submitted to the previous respondents have been tested on 30 samples outside the population and the results were measured the validity using the Pearson's Product-Moment method, and the reliability test with the alpha Cronbach value is a reliable statement if the value is more than $0.70(>0.70)$. Following are the results of the calculation using SPSS:

Table 1. Summary of Research Instrument Test Results

\begin{tabular}{clccc}
\hline No. & \multicolumn{1}{c}{ Variables } & Valid Items & $\begin{array}{c}\text { Alpha Croanbach's } \\
\text { Value }\end{array}$ & Information \\
\hline 1 & Work motivation & 21 & 0.875 & Valid and Reliable \\
2 & Organizational culture & 29 & 0.915 & Valid and Reliable \\
3 & Transformational leadership & 34 & 0.965 & Valid and Reliable \\
\hline
\end{tabular}

1) The statement before the validity test was as many as 40 items then a statement was taken according to the provisions, namely coefficient $>0.361$ ( $\mathrm{r}$ table).

2) Statements that are already valid are then tested for reliability.

\section{Data Analysis Techniques}

The data analysis in this research is quantitative in nature with the following steps:

1. Calculating the distribution data including maximum, minimum, variance, standard deviation, and centered data, namely mean (mean), middle value (media), frequently occurring values (mode)

2. Perform standard error normality test using the Liliefors method.

3. Conduct Linearity Test to determine the relationship between research variables

4. Conducting Hypothesis Testing with Path Analysis, namely the SPSS application. 


\section{RESULTS AND RESEARCH DISCUSSION}

Based on the results of statistical calculations on the variable data of work motivation, organizational culture, and transformational leadership, it is described in the following table:

Table 2. Statistical Description

\begin{tabular}{clccc}
\hline No. & Statistical Description & $\begin{array}{c}\text { Work } \\
\text { Motivation }\end{array}$ & $\begin{array}{c}\text { Organizational } \\
\text { Culture }\end{array}$ & $\begin{array}{c}\text { Transformational } \\
\text { Leadership }\end{array}$ \\
\hline 1 & Sample & 153 & 135 & 135 \\
2 & Statement Items & 21 & 29 & 34 \\
3 & Minimum Value & 105 & 141 & 170 \\
4 & Maximum Value & 60 & 83 & 77 \\
5 & Total Variable Value & 13,259 & 17,728 & 21,362 \\
6 & Mean & 85.14 & 115.87 & 139.62 \\
7 & Mode & 87 & 110 & 136 \\
8 & Median & 82.5 & 112.5 & 123.5 \\
9 & Standard Deviation & 7,899 & 11,235 & 20,227 \\
10 & Variance & 62,396 & 126,233 & 409,145 \\
\hline
\end{tabular}

The results of the standard error normality test using the Liliefors method are summarized in the following table:

Table 3. Summary of Normality Test Results

\begin{tabular}{llll}
\hline \multicolumn{1}{c}{ Variable } & Lcount & Ltable & \multicolumn{1}{c}{ Conclusion } \\
\hline Organizational Culture (X1) & 0.0628 & $<0.0716$ & Normal \\
Transformational Leadership (X2) & 0.0678 & $<0.0716$ & Normal \\
Work Motivation (Y) & 0.0703 & $<0.0716$ & Normal \\
\hline
\end{tabular}

Lcount> Ltable: Standard Error Not Normal

Lcount<Ltable: Normal Default Error

Based on the results of the standard error calculation using the Liliefors method, it shows that the Lcount value of all variables is below the value of 0.0716 (Ltable), so the questionnaire data for the variables of organizational culture, transformational leadership, and employee work motivation comes from a normal population.

The results of the linearity test on the variable data of organizational culture (X1), transformational leadership (X2), and work motivation (Y) are as stated in Table 4:

Table 4. Linearity Test Results

\begin{tabular}{lccc}
\hline Variable & $\begin{array}{c}\text { Significance of } \\
\text { Deviation From } \\
\text { Linearity }\end{array}$ & Information & Conclusion \\
\hline $\mathrm{X} 1 \rightarrow \mathrm{Y}$ & 0.051 & $>0.05$ & Linear \\
$\mathrm{X} 2 \rightarrow \mathrm{Y}$ & 0.141 & $>0.05$ & Linear \\
\hline \multicolumn{3}{c}{ Sig. Deviation From Linearity<0.05: Non-Linear } \\
& Sig. Deviation From Linearity> $0.05:$ Linear & \\
\hline
\end{tabular}

Based on this data, in general, all variables have a (linear) relationship. 


\section{Path Analysis Results}

The path analysis calculation for the path hypothesis is carried out by forming two equations as shown in Figure 2.

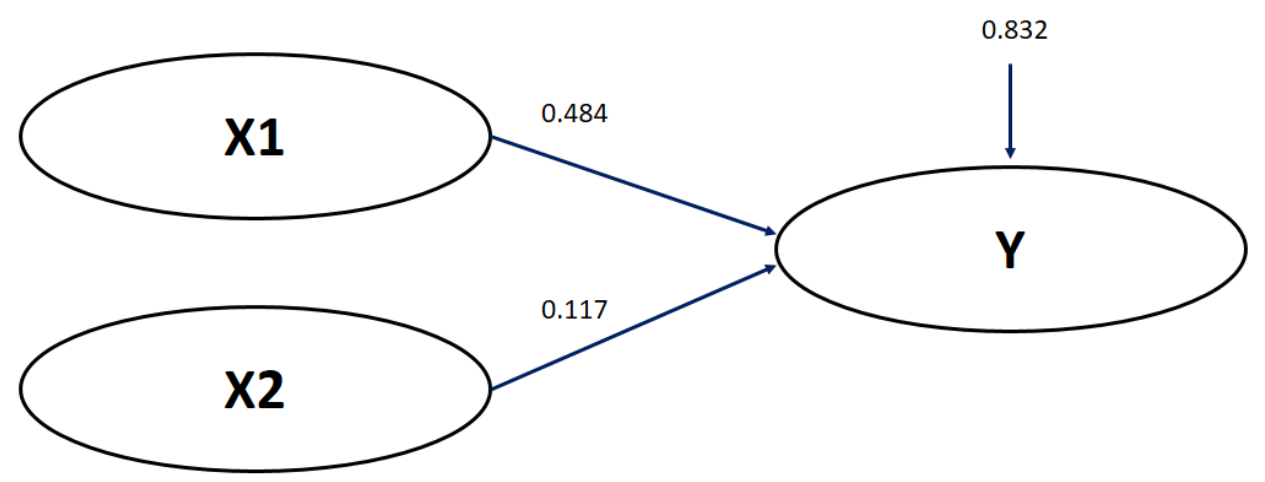

Figure 2. Structural Equation Models

With the value of each variable as referred to in Table 5 below:

Table 5.The Results of The Path Diagram

\begin{tabular}{ccccc}
\hline $\begin{array}{c}\text { Constant } \\
(\mathbf{a})\end{array}$ & Sig value. $(<\mathbf{0 . 0 5})$ & $\begin{array}{c}\text { Path coefiscient } \\
(\boldsymbol{\beta})\end{array}$ & $\begin{array}{c}\text { Adjusted } \\
\boldsymbol{R}^{\mathbf{2}}\end{array}$ & $\boldsymbol{\varepsilon}$ \\
\hline 39.293 & $\mathrm{X} 1 \rightarrow \mathrm{Y}=0.000$ (significant) & 0.484 & 0.307 & 0.832 \\
& $\mathrm{X} 2 \rightarrow \mathrm{Y}=0.167$ (not significant) & 0.117 & $(30.7 \%)$ & \\
\hline
\end{tabular}

Then the form of the equation is; $\mathrm{Y}=\mathrm{a}+\beta \mathrm{X} 1+\beta \mathrm{X} 2+\varepsilon 1=39.293+0.484 \mathrm{X} 1+0.117 \mathrm{X} 2+0.832$.

the value of Sig. organizational culture $(\mathrm{X} 1)$ of $0.000<0.05$ means that it is significant to work motivation $(\mathrm{Y})$ of employees, the value of Sig. transformational leadership (X2) of 0.167>0.05 means that it is not significant for employee motivation (Y). The Adjusted R Square value of 0.307 means that Organizational culture and transformational leadership simultaneously have an effect on $30.7 \%$ of the remaining work motivation (Y) of employees and $69.3 \%$ are influenced by other factors not examined.

Based on table 5 above, organizational culture (X1) has a significant effect on work motivation (Y), meaning that the first hypothesis of this study (H1) is supported. Thus that the organizational culture includes factors 1 ) Innovation and risk-taking: the extent to which employees are encouraged to be innovative and take risks. 2) Attention to details: the extent to which employees are expected to demonstrate accuracy, analysis, and depth of attention to details. 3) Outcome orientation: the extent to which management focuses on results or outcomes rather than on the techniques and processes to achieve these results. 4) People orientation: the extent to which management decisions take into account the impact of work results on people in the organization. 5) Team orientation: the extent to which work activities are coordinated in teams rather than individuals. 6) Aggressiveness: aggressive and competitive. 7) Stability: the extent to which organizational activities emphasize the importance of efforts to maintain organizational stability,

Based on table 5 above, transformational leadership (X2) does not have a significant effect on work motivation $(\mathrm{Y})$, meaning that the second hypothesis of this study $(\mathrm{H} 2)$ is not supported nor rejected. Thus the application of Transformational Leadership by employee superiors includes; 1) Idealized Influence, which describes a leader who acts as a strong role model for followers. 2) Inspirational motivation, leaders who inspire them through motivation to commit and part of a shared vision in the organization. 3) Intellectual stimulation, leadership that 
stimulates followers to be creative and innovative. 4) Individualized consideration, leaders who provide a supportive climate where they listen carefully to the individual needs of employees,

\section{CONCLUSIONS AND SUGGESTIONS}

Based on the results of research and discussion of the influence of organizational culture and transformational leadership on work motivation carried out on Echelon IV (supervisors) Offices and Bodies in the Bogor Regency Government, the following conclusions are produced: (1) Organizational culture has a significant effect on work motivation, (2) Transformational leadership has no significant effect on work motivation. Based on these conclusions, to increase the motivation of employees in the Bogor Regency Government are as follows:First: Increase Work Motivation through Organizational Culture. To strengthen employee Work Motivation, the leadership needs to continue internalizing the values contained in the current Organizational Culture, namely "GERCEP" to be able to provide Work Motivation for employees, it can be done by implementing policies that emphasize the factors; trying new ideas/experimenting in carrying out tasks or in public service, being careful at work, having results, being aggressive, maintaining organizational stability by implementing good rules and emphasizing teamwork, this can create favorable working conditions. good and rewards for those who excel, to encourage employees to work more optimally.Second: Upgrade Work Motivation through improvement and enhancement of Transformational Leadership practices. To increase Work motivation through transformational leadership, suggestions for implementation are to provide an understanding of leadership practices from leaders in organizational units (especially employee superiors) which include factors (a) role models that can provide real examples of subordinates' behavior, so that raises the awareness of individuals to work well, loves work and is innovative, (b) gives high expectations (enthusiasm) to employees so that they carry out tasks with enthusiasm, leaders must also be able to create a harmonious working atmosphere that is conducive and inspire to always produce things new in the implementation of tasks / jobs (c) analytical thinking, namely by developing an open mindset, always inviting subordinates to work hard, achieve,competitive in producing work that is best for the benefit of the organization, (d) considering individuals, namely by paying attention to each subordinate, communicating well with all employees, and making every decision making always consider the impact on subordinates.

Suggestions for further research are to first research with different units of analysis or in a broader scope of all employees, not only limited to echelon IV (supervisors) employees in regional government as well as in higher and wider levels of government. The two further studies can use tested variables, namely organizational culture, transformational leadership through work motivation as an intervening variable combined with other variables.

\section{REFERENCES}

[1] Aunjum, A. H., Abbas, G., \& Sajid, M. (2017). Transformational Leadership and Employee Motivation in Banking Sector of Pakistan. Advances in Economics and Business, 5(9), 487-494.

[2] Chen, S.-C., Wu, M.-C., \& Chen, C.-H. (2010). Employee's personality traits, work motivation and innovative behavior in marine tourism industry. Journal of Service Science and Management, 3(02), 198.

[3] Colquitt Jasson, A., Jeffery, A., \& Lepine, M. J. W. (2009). Organizational Behavior. New York: Mc Graw Hill.

[4] Devadass, R. (2011). Employees Motivation in Organizations: An integrative literature. International Conference on Sociality and Economics Development IPEDR, Vol. 10, 566-670.

[5] Fischer, C., Malycha, C. P., \& Schafmann, E. (2019). The influence of intrinsic motivation and synergistic extrinsic motivators on creativity and innovation. Frontiers in Psychology, 10, 137.

[6] George, J. M., Jones, G. R., \& Sharbrough, W. C. (2005). Understanding and managing organizational behavior. Pearson Prentice Hall Upper Saddle River, NJ.

[7] Gibson, J. L., Ivancevich, J. M., Donnelly, J. H., \& Konopaske, R. (1991). Organizations: Behavior, structure, processes. Irwin Homewood, IL.

[8] Lin, C. Y., \& Liu, F. (2012). A cross- level analysis of organizational creativity climate and perceived innovation. European Journal of Innovation Management.

[9] Northouse, P. G. (2018). Leadership: Theory and practice. Sage publications.

[10] Robbins, S. P., \& Coulter, M. (2017). Management 13E. Pearson India.

[11] Yusof, H. S. M., Said, N. S. M., \& Ali, S. R. O. (2016). A study of organizational culture and employee motivation in private sector company. J Appl Environ, 6, 50-54. 